Kahoru Nishina MD, Katsuya Mikawa MD, Nobuhiro Maekawa MD, Masako Tamada MD, Hidefumi Obara MD

\section{Omeprazole reduces preoperative gastric fluid acidity and volume in children}

anaesthesia. These data also suggest that this drug, when administered in a single dose of approximately $1.0 \mathrm{mg} \cdot \mathrm{kg}^{-1}$ three hours before surgery, is ineffective in increasing gastric fluid pH to $>2.4$.

Cette étude évalue à la période préopératoire les effets de l'oméprazole oral sur le liquide et le volume gastriques des enfants. Cent quatre patients hospitalisés âgés de quatre à neuf ans sont répartis au hasard en quatre groupes $(n=26)$. Le groupe oméprazole-oméprazole reçoit deux doses d'oméprazole $(20 \mathrm{mg}$ par dose), le groupe placebo, deux doses de placebo, les groupes placebo-oméprazole et oméprazole-placebo, chacun une dose des deux préparations orales. La première médication est toujours administrée à 9.00 p.m. la veille de la chirurgie et la seconde à 5.30 a.m. le matin de la chirurgie (trois heures avant lintervention). Les enfants programmés pour une chirurgie élective peuvent boire $10 \mathrm{ml} \cdot \mathrm{kg}^{-1}$ de jus de pomme trois heures avant l'anesthésie. Après linduction de l'anesthésie, le liquide gastrique est aspiré par une sonde orale de gros calibre à plusieurs orifices et analysé pour son $\mathrm{pH}$ et son volume total. L'oméprazole administré au coucher augmente le pH (3,3 \pm 1,3 vs 2,0 $\pm 0,6, P<0,05$ ) comparativement au placebo, ainsi que les deux doses d'oméprazole $(p H=4,8 \pm 1,6, P<0,05)$. Une dose unique d'oméprazole administrée le matin de la chirurgie n'augmente pas le $\mathrm{pH}$ gastrique. On note une réduction du nombre d'enfants à $\mathrm{pH}<2,5$ et à volume $>0,4 \mathrm{ml} \cdot \mathrm{kg}^{-1}$ dans les groupes oméprazole-oméprazole et oméprazole-placebo comparativement aux groupes placebo-placebo et oméprazoleplacebo. L'administration d'oméprazole $20 \mathrm{mg}$ le soir qui précède la chirurgie améliore les conditions gastriques à lïnduction de l'anesthésie pour ainsi diminuer le risque de pneumonite d'aspiration. Ces données suggèrent aussi que l'oméprazole administré en dose unique de $1,0 \mathrm{mg} \cdot \mathrm{kg}^{-1}$ trois heures avant la chirurgie n'augmente pas le $\mathrm{pH}$ gastrique à un niveau $>2,4$.

Omeprazole is a new potent gastric antisecretory agent which, unlike $\mathrm{H}_{2}$-antagonists, inhibits the final common pathway of gastric acid secretion $\mathrm{H}^{+} / \mathrm{K}^{+}-$ATPase (proton pump). ${ }^{1}$ The drug produces rapid and prolonged inhibition of this enzyme ${ }^{2}$ and has been used orally in 
the treatment of recurrent peptic ulceration, reflux oesophagitis, and Zollinger Ellison syndrome. ${ }^{3-5}$ Furthermore, successful use of omeprazole has been reported in children with reflux oesophagitis refractory to routine treatment with $\mathrm{H}_{2}$-antagonists ${ }^{6}$ or familial $\mathrm{G}$-cell hyperfunction. ${ }^{7}$ The drug has been recently reported to be effective as a premedicant by increasing gastric fluid $\mathrm{pH}$ and decreasing gastric fluid volume in adults. ${ }^{8-11}$ We undertook the current prospective study to evaluate the efficacy of preoperative oral omeprazole in controlling gastric fluid $\mathrm{pH}$ and volume in children.

\section{Methods}

After institutional approval of the clinical investigation review board and parental informed consent of all children, we examined the effects of omeprazole on gastric fluid volume and $\mathrm{pH}$ in 104 otherwise healthy children (in-patients of ASA physical status I), aged 4-9 yr, undergoing elective surgery as in-patients. Patients with gastrointestinal disease, obese patients who were more than $20 \%$ heavier than their ideal body weight, and those taking medication known to affect gastric fluid composition or gastric emptying were excluded. The children were randomly assigned to one of four treatments as follows ( $n=26$ for each group): Omeprazole-Omeprazole, Placebo-Placebo (as a control group), PlaceboOmeprazole, and Omeprazole-Placebo; subjects in the Omeprazole-Omeprazole Group received two doses of omeprazole $\left(20 \mathrm{mg}\right.$ per dose, Omepral ${ }^{\circledR}$, Fujisawa, Japan), those in the Placebo-Placebo Group, two doses of placebo, those in the Placebo-Omeprazole and Omeprazole-Placebo Groups, one dose each of the two preparations by mouth. For each treatment regimen, the first medication was administered at 9:00 p.m. on the night before surgery and the second at 5:30 a.m. on the morning of the day of surgery.

Table I indicates these patients' profiles. Milk and solids were administered until 9:00 p.m. on the day before surgery. The patients were instructed to ingest a large volume of apple juice $\left(10 \mathrm{ml} \cdot \mathrm{kg}^{-1}\right)$ three hours before induction of anaesthesia (at 5:30 a.m. on the day of surgery).

Induction of anaesthesia in all cases was started at 8:30 a.m. After preoxygenation with $100 \%$ oxygen by mask, anaesthesia was induced with nitrous oxide $\left(\mathrm{N}_{2} \mathrm{O}\right)$ $4 \mathrm{~L} \cdot \min ^{-1}$, oxygen $2 \mathrm{~L} \cdot \mathrm{min}^{-1}$, and halothane in gradually increasing concentrations up to $1.5 \%$. Infusion (lactated Ringer's solution) was started immediately after we confirmed loss of consciousness of children. Atropine 0.01 $\mathrm{mg} \cdot \mathrm{kg}^{-1} \dot{\boldsymbol{N}}$ was then administered through a three-way stopcock to prevent bradycardia and hypotension. After injection of atropine, halothane was increased to $2.5 \%$. The lungs were ventilated taking care to avoid inflation of the stomach. Tracheal intubation was facilitated by vecuronium bromide $0.1 \mathrm{mg} \cdot \mathrm{kg}^{-1} \dot{i v}$. All inductions were uneventful and no patients had coughing, laryngospasm, or vomiting during induction.

Following tracheal intubation, a 16-Fr Argyle Salem Sump ${ }^{\circledR}$ catheter was inserted into the stomach. Placement of the orogastric tube within the stomach was verified by auscultation over the epigastrium during introduction of 5-10 mL air. Gastric fluid samples were obtained by gentle aspiration with a $50 \mathrm{ml}$ syringe by an investigator who was unaware of the patients preanaesthetic medication. Aspirations were attempted with the child held in supine, reverse Trendelenburg's, and both lateral positions to maximize gastric emptying. Pressure was applied over the epigastrium with the patient supine and then in the left and right lateral decubitus positions to ensure maximum emptying of gastric fluid. Gastric contents were visually inspected for particles and the volume of gastric contents was measured with the syringe. The $\mathrm{pH}$ of the gastric fluid was determined immediately using a pH meter (Horiba F-8L, Japan) which was calibrated using standard buffers at $\mathrm{pH}$ values of 4,7 , and 9. The $\mathrm{pH}$ meter has $0.01 \mathrm{pH}$ units precision over the entire $\mathrm{pH}$ range. The gastric fluid $\mathrm{pH}$ was also determined using $\mathrm{pH}$ indicator paper $\left(\right.$ Acilit $^{\circledR}$, Merck, Germany and Advantec ${ }^{\circledR}$, Toyo Roshi, Japan). After approximate gastric $\mathrm{pH}$ was estimated by Alicit ${ }^{\circledR} \mathrm{pH}$ test paper, we could determine it more accurately at intervals of 0.1 using a series of Advantec ${ }^{\circledR}$ (CR, TB, BPB, BCG, $\mathrm{CPR}$, and $\mathrm{BTB}$ ), which covers a $\mathrm{pH}$ range from 0.4 to 9.6. In comparing the results of the different methods of testing gastric fluid properties used in the study, we found that, even for gastric aspirate $\mathrm{pH}$ levels $<2.5$, measurements obtained by the $\mathrm{pH}$ meter correlated well with values determined by the method of $\mathrm{pH}$ test paper ( $\mathrm{r}$ $=0.96$ ) (data not shown).

The age, weight, the volume of apple juice ingested, and gastric fluid $\mathrm{pH}$ and volume were recorded for each patient.

Comparisons of data between the groups were made using one-way analysis of variance and Bonferroni correction for multiple comparison of parametric data, while Kruskal-Wallis rank test was used for non-parametric data. The differences between the groups' risk factors for pulmonary acid-aspiration syndrome were tested for statistical significance by chi-square test. $P<0.05$ was deemed statistically significant.

\section{Results}

There were no differences among the four groups with regard to age, weight, or volume of fluids ingested (Table I).

Although gastric fluid was obtained from all children 
TABLE I Demographic data. Values are expressed as mean \pm SD

\begin{tabular}{lllll}
\hline Groups & $\begin{array}{l}\text { Placebo- } \\
\text { Placebo }\end{array}$ & $\begin{array}{l}\text { Omeprazole- } \\
\text { Placebo }\end{array}$ & $\begin{array}{l}\text { Placebo- } \\
\text { Omeprazole }\end{array}$ & $\begin{array}{l}\text { Omeprazole- } \\
\text { Omeprazole }\end{array}$ \\
\hline$n$ & 26 & 26 & 26 & 26 \\
Age $(\mathrm{yr})$ & $5.7 \pm 1.5$ & $5.9 \pm 1.6$ & $5.8 \pm 1.5$ & $6.1 \pm 1.4$ \\
$\begin{array}{l}\text { Weight }(\mathrm{kg}) \\
\text { Volume of apple juice } \\
\text { ingested }\left(\mathrm{ml} \cdot \mathrm{kg}^{-1}\right)\end{array}$ & $20 \pm 3.9$ & $21 \pm 3.6$ & $22 \pm 4.0$ & $22 \pm 4.1$ \\
\hline
\end{tabular}

TABLE II Gastric fluid analysis

\begin{tabular}{|c|c|c|c|c|}
\hline & $\begin{array}{l}\text { Placebo- } \\
\text { Placebo }\end{array}$ & $\begin{array}{l}\text { Omeprazole- } \\
\text { Placebo }\end{array}$ & $\begin{array}{l}\text { Placebo- } \\
\text { Omeprazole }\end{array}$ & $\begin{array}{l}\text { Omeprazole- } \\
\text { Omeprazole }\end{array}$ \\
\hline \multicolumn{5}{|l|}{ Gastric fluid volume $\left(\mathrm{ml} \cdot \mathrm{kg}^{-1}\right)$} \\
\hline $\begin{array}{l}- \text { mean } \pm \mathrm{SD} \\
- \text { (range) } \\
\text { Gastric fluid } \mathrm{pH}\end{array}$ & $\begin{array}{l}0.67 \pm 0.56 \\
(0-3.0)\end{array}$ & $\begin{array}{l}0.23 \pm 0.14^{*} \dagger \\
(0-0.47)\end{array}$ & $\begin{array}{l}0.39 \pm 0.19^{*} \\
(0-0.82)\end{array}$ & $\begin{array}{l}0.20 \pm 0.10^{*} \dagger \\
(0-0.46)\end{array}$ \\
\hline $\begin{array}{l}- \text { mean } \pm S D \\
\text { - (range) }\end{array}$ & $\begin{array}{l}2.01 \pm 0.59 \\
(0.8-3.8)\end{array}$ & $\begin{array}{l}3.32 \pm 1.28^{*} \dagger \\
(0.9-7.2)\end{array}$ & $\begin{array}{l}2.49 \pm 1.12 \\
(0.9-6.7)\end{array}$ & $\begin{array}{l}4.84 \pm 1.55^{*} \dagger \\
(2.4-7.3)\end{array}$ \\
\hline $\begin{array}{l}\text { Gastric fluid volume }>0.4 \mathrm{ml} \cdot \mathrm{kg}^{-1} \\
\text { and gastric fluid } \mathrm{pH}<2.5\end{array}$ & $11 / 26(42 \%)$ & $3 / 26(12 \%)^{* \dagger}$ & $10 / 26(38 \%)$ & $1 / 26(4 \%)^{*} \dagger$ \\
\hline
\end{tabular}

${ }^{*} P<0.05$ vs Placebo-Placebo (control) Group.

$\dagger P<0.05$ vs Placebo-Omeprazole Group.

enrolled in the current study, the volume was sufficient for $\mathrm{pH}$ determination in only 80 of the 104 samples. In the remainder, a very small quantity of gastric fluid remained in the gastric tube and it could not be aspirated into the syringe. Such an insufficient quantity of gastric aspirate precluded measurements; these small quantities of gastric fluid were arbitrarily regarded as a residual volume of $0 \mathrm{ml}$. Gastric fluid volume was greater with the Placebo-Placebo (control) than with any of the other three regimens (Table II.) The Omeprazole-Placebo and Omeprazole-Omeprazole groups had lower volumes of gastric aspirate than the Placebo-Omeprazole group. In the former groups, gastric fluid volume was similar. The Omeprazole-Placebo and Omeprazole-Omeprazole groups had greater gastric fluid $\mathrm{pH}$ than did the PlaceboPlacebo and Placebo-Omeprazole groups, which had similar gastric $\mathrm{pH}$ values (Table II).

Table II shows a number of children with gastric fluid volume greater than $0.4 \mathrm{ml} \cdot \mathrm{kg}^{-1}$ and gastric fluid $\mathrm{pH}$ less than 2.5. The control and Placebo-Omeprazole Groups had a similar proportion with a gastric $\mathrm{pH}<2.5$ and gastric volume $>0.4 \mathrm{ml} \cdot \mathrm{kg}^{-1}$ (Placebo-Placebo: 46\% and Placebo-Omeprazole: 38\%). In both groups where omeprazole was administered on the night before surgery, there was a difference in the proportion of subjects with the gastric $\mathrm{pH}$ less than 2.5 and gastric volume greater than $0.4 \mathrm{ml} \cdot \mathrm{kg}^{-1}$ (Omeprazole-Placebo: $11 \%$ and Omeprazole-Omeprazole: $4 \%$ ).
No children had particulate matter in their gastric aspirates. No adverse side effects (rash, headache, diarrhoea, and fever) were observed.

\section{Discussion}

The onset of the gastric anti-secretory effect of omeprazole after a single oral dose occurs within two to six hours. ${ }^{12,13}$ Omeprazole has a prolonged effect (duration $>24 \mathrm{hr})^{13,14}$ because it is concentrated selectively in the acidic environment of the gastric parietal cell, where it remains at high level for a long period of time. ${ }^{15}$ This pharmacological characteristic may account for our observation that oral omeprazole, even when given in a single dose at bedtime before surgery, effectively increased gastric $\mathrm{pH}$ and decreased gastric volume. Omeprazole, $20 \mathrm{mg}$ orally taken the night before surgery and again on the morning of the day of surgery, increased gastric $\mathrm{pH}$ more consistently than a single dose of omeprazole at night before surgery. In contrast, a single $20 \mathrm{mg}$ oral dose of omeprazole administered on the morning of the day of surgery (three hours before surgery) failed to improve the gastric aspirate environment. Although the reason for this failure is unknown, the rapid onset of omeprazole observed in adults may not hold true for children and three hours may be too short a time interval. Furthermore, these data suggest that omeprazole given in a single oral dose preoperatively is not suitable for ambulatory surgery patients who arrive two hours before 
surgery for their premedication. In a previous adult study, a single oral dose of omeprazole was administered 279 $\min$ (mean) before induction of anaesthesia showed that the drug was effective in reducing gastric fluid volume and acidity." Thus, omeprazole should have been administered to patients in the Placebo-Omeprazole Group more than three hours before induction of anaesthesia. However, a feeling of compassion toward children who are to be aroused from sleep at midnight to receive the premedication precluded us from giving them medication at such a time.

Although many studies of $\mathbf{H}_{2}$-antagonists have been carried out in children, ${ }^{16-22}$ their comparability with the current study is quite limited because of discrepancies in patient selection, time of administration and anaesthetic regimen used. However, since the reduction in gastric fluid volume is not a consistent finding in studies of $\mathrm{H}_{2}$-antagonists, ${ }^{18-22}$ the ability of omeprazole to decrease gastric volume may be an advantage of $\mathrm{H}_{2-}$ antagonists. A rebound increase in gastric secretion following discontinuation of medication seems to occur less frequently with omeprazole than with cimetidine. ${ }^{23}$ Omeprazole has little effect on haemodynamics. ${ }^{24}$ These characteristics may also be advantages of the drug. Since $\mathrm{H}_{2}$-antagonists (cimetidine and ranitidine) given one to two hours before surgery have been demonstrated to increase gastric fluid $\mathrm{pH}$ in children successfully, ${ }^{21}$ these drugs may be more suitable for paediatric out-patients as a premedicant than omeprazole.

As the incidence of aspiration has been recently reported to be approximately $1: 10,000,{ }^{25-27}$ it is extremely unlikely that aspiration will occur in children who are not predisposed to regurgitation. Thus, prophylaxis of aspiration pneumonitis with omeprazole for otherwise healthy children may have fewer clinical implications. However, its use might be considered in cases where airway difficulties are anticipated. ${ }^{28}$ Children with trauma may be another group of patients who may benefit because these patients are likely to have delayed gastric emptying and even prolonged fasting will not be helpful in all cases. ${ }^{29}$

The rationale for administration of omeprazole $20 \mathrm{mg}$ per dose is based on the following data from other laboratories. Omeprazole has an accepted place in clinical practice for the treatment of severe reflux oesophagitis, recurrent peptic ulcer, and Zollinger Ellison syndrome in adults. ${ }^{3-5}$ For these purposes, oral administration of omeprazole at doses of $0.3-1.1 \mathrm{mg} \cdot \mathrm{kg}^{-1} \cdot$ day $^{-1}$ (assuming a $70 \mathrm{~kg}$ adult) for several months is advocated. ${ }^{3-5,30}$ A single $0.6-1.1 \mathrm{mg} \cdot \mathrm{kg}^{-1}$ dose administered on the night before surgery in adults has been shown to be effective in reducing the number of patients at increased risk for acid aspiration syndrome. ${ }^{8-10}$ In three children (aged 8-15 yr) with reflux oesophagitis refractory to $\mathrm{H}_{2}$-antagonists, initial treatment with oral omeprazole $40 \mathrm{mg} \cdot$ day $^{-1}$ for several weeks and maintenance treatment with 20 $\mathrm{mg} \cdot \mathrm{day}^{-1}$ for more than 24 mo were effective in ameliorating symptoms (retrosternal pain, haematemesis, and recurrent aspiration pneumonia) and endoscopic finding (ulcer formation) of this disease. ${ }^{6}$ Another prospective study in children (aged 5 mo-18 yr) with peptic oesophagitis has led to the conclusion that omeprazole at 20 $\mathrm{mg} \cdot \mathrm{day}^{-1}$ for six to eight weeks is effective in reducing symptoms. ${ }^{31}$ Long-term treatment with oral omeprazole ( $20 \mathrm{mg} \cdot \mathrm{day}^{-1}$ for three years) in a child with severe peptic disease associated with antral $\mathrm{G}$ cell hyperfunction has been shown to result in symptom abatement and a return of laboratory values to normal. ${ }^{7}$ No adverse effects were observed in these reports. Omeprazole is a weak base $(\mathrm{pKa}=4)$ and is inactivated rapidly in acid environments. ${ }^{32}$ Omeprazole is therefore formulated as an enteric coated tablet to enhance absorption from the small intestine. This characteristic of omeprazole precluded us from pulverizing the tablets. Furthermore, in the present study, doses of $0.7-1.5 \mathrm{mg} \cdot \mathrm{kg}^{-1}$ were used because 20 $\mathrm{mg}$ tablets are the only dosage form available in Japan. Thus, we studied the upper dose range of this medication. However, $10 \mathrm{mg}$ tablets are available in some countries, where the effect of the optimal dose may be evaluated.

In conclusion, we have shown that oral omeprazole, $20 \mathrm{mg}$, administered on the night before surgery improved the gastric environment in children the following morning, whereas a single dose given three hours before surgery was ineffective. In subjects who are at risk of aspirating gastric contents, the reduction in volume of gastric fluid and the improvement of gastric $\mathrm{pH}$ may reduce the occurrence of pneumonitis, should regurgitation and aspiration of gastric contents occur.

\section{References}

1 Wallmark B, Jaresten B-M, Larsson H, Ryberg B, Brandström $A$, Fellenius $E$. Differentiation among inhibitory actions of omeprazole, cimetidine, and $\mathrm{SCN}^{-}$on gastric acid secretion. Am J Physiol 1983; 245: G64-G71.

2 Regårdh C-G, Gabrielsson M, Hoffman KJ, Löfberg I, Skånberg $I$. Pharmacokinetics and metabolism of omeprazole in animals and man - an overview. Scand J Gastroenterol 1985; 20: 79-94.

3 Clissold SP, Campoli-Richards DM. Omeprazole: a preliminary review of its pharmacodynamic and pharmacokinetic properties, and therapeutic potential in peptic ulcer disease and Zollinger-Ellison syndrome. Drugs 1986; 32: 15-47.

4 Protzer $U$, Holtermüller $\mathrm{KH}$. Omeprazoe. Pharmakologie und therapeutische Wirksamkeit. Dtsch Med Wochenschr 1993; 118: 230-9. 
5 Biemond I, Klinkenberg-Knol EC, Lamers CBHW, Meuwissen SGM. Serum pepsinogens after interruption of long-term maintenance therapy with omeprazole in patients with reflux esophagitis. Dig Dis Sci 1993; 38: 932-6.

6 Nelis $G F$, Westerveld $B D$. Treatment of resistant reflux oesophagitis in children with omeprazole. European Journal of Gastroenterology and Hepatology 1990; 2: 215-7.

7 De Giacomo C, Fiocca R, Villiani L, Licardi G, Scotta $M S$, Solcia $E$. Omeprazole treatment of severe peptic disease associated with antral $G$ cell hyperfunction and hyperpepsinogenemia I in an infant. J Pediatr 1990; 117: 989-93.

8 Cruickshank RH, Morrison DA, Bamber PA, Nimmo $W S$. Effect of i.v. omeprazole on the $\mathrm{pH}$ and volume of gastric contents before surgery. Br J Anaesth 1989; 63: 536-40.

9 Gin T, Ewart MC, Yau G, Oh TE. Effect of oral omeprazole on intragastric $\mathrm{pH}$ and volume in women undergoing elective Caesarean section. Br J Anaesth 1990; 65: 616-9.

10 Ewart MC, Yau G, Gin T, Kotur CF, Oh TE. A comparison of the effects of omeprazole and ranitidine on gastric secretion in women undergoing elective Caesarean section. Anaesthesia 1990; 45: 527-30.

11 Hendolin H, Suojaranta-Ylinen R, Alhava E. Effect of single-dose omeprazole and ranitidine on gastric juice acidity and volume in patients undergoing laparotomy. Acta Anaesthesiol Scand 1993; 37: 484-7.

12 Inoue $M$, Shirakawa $T$, Kajiyama $G$, et al. Clinical study of a proton pump inhibitor, omeprazole (1). The effect on gastric acid secretion by continuous intragastric $\mathrm{pH}$ monitoring. Basic Pharmacol Ther 1988; 16: 493-503.

13 Olbe $L$, Lind T, Cederberg C, Ekenved $G$. Effect of omeprazole on gastric acid secretion in man. Scand J Gastroenterol Suppl 1986; 21: 105-7.

14 Brunton $L L$. Agents for control of gastric acidity and treatment of peptic ulcers. In: Gilman AG, Rall TW, Nies AS, Taylor P (Eds.). Goodman and Gilman's The Pharmacological Basis of Therapeutics (8th ed.). New York: Pergamon Press, 1990; 897-913.

15 Helander HF, Ramsay C-H, Regårdh C-G. Localization of omeprazole and metabolites in the mouse. Scand J Gastroenterol Suppl 1985; 20: 95-104.

16 Goudsouzian N, Coté CJ, Liu LMP, Dedrick DF. The dose-response effects of oral cimetidine on gastric $\mathrm{pH}$ and volume in children. Anesthesiology 1981; 55: 533-6.

17 Goudsouzian NG, Young ET. The efficacy of ranitidine in children. Acta Anaesthesiol Scand 1987; 31: 387-90.

18 Jahr JS, Burckart G, Smith SS, Shapiro J, Cook DR. Effects of famotidine on gastric $\mathbf{p H}$ and residual volume in pediatric surgery. Acta Anaesthesiol Scand 1991; 35: 457-60.

19 Tryba $M$, Yildiz $F$, Kühn $K$, Dziuba $M$, Zenz $M$. Rectal and oral cimetidine for prophylaxis of aspiration pneumoni- tis in paediatric anaesthesia. Acta Anaesthesiol Scand 1983; 27: $328-30$.

20 Christensen S, Farrow-Gillespie A, Lerman J. Effects of ranitidine and metoclopramide on gastric fluid $\mathrm{pH}$ and volume in children. $\mathrm{Br} J$ Anaesth 1990; 65: 456-60.

21 Guay J, Santerre L, Gaudreault P, Goulet B, Dupuis C. Effects of oral cimetidine and ranitidine on gastric $\mathrm{pH}$ and residual volume in children. Anesthesiology 1989; 71: 547-9.

22 Kemmotsu $O$, Mizushima M, Morimoto Y, et al. Effect of preanesthetic intramuscular ranitidine on gastric acidity and volume in children. J Clin Anesth 1991; 3: 451-5.

23 Yoshinari $M$, Minamida $Y$. New drug information from DI. Pharma Medica 1991; 9: 165-76.

24 Fujisawa Pharmaceutical Industries. Data on file: outline of Omepral ${ }^{\oplus}$. Fujisawa Pharmaceutical Industries, Osaka, Japan.

25 Olsson GL, Hallen B, Hambraeus-Jonzon K. Aspiration during anaesthesia: a computer-aided study of 185,358 anaesthetics. Acta Anaesthesiol Scand 1986; 30: 84-92.

26 Tiret $L$, Nivoche $Y$, Hatton $F$, Demonts $J M$, Vourc'h $G$. Complications related to anaesthesia in infants and children. Br J Anaesth 1988; 61: 263-9.

27 Tiret L, Demonts JM, Hatton F, Vourch G. Complications associated with anaesthesia - a prospective survey in France. Can Anaesth Soc J 1986; 33: 336-44.

28 Weaver $M K$. Perioperative pulmonary aspiration in children: a review. Paediatric Anaesthesia 1993; 3: 333-8.

29 Bricker SRW, McLuckie A, Nightingale DA. Gastric aspirates after trauma in children. Anaesthesia 1989; 44: 721-4.

30 Naesdal J, Lind T, Bergsåker-Aspöy J, et al. The rate of healing of duodenal ulcers during omeprazole treatment. Scand J Gastroenterol 1985; 20: 691-5.

21 Karjoo $M$, Kane RE. Omeprazole treatment in children with peptic esophagitis refractory to ranitidine. Gastroenterol 1992; 102: A93.

32 Rowbotham DF. Omeprazole - a useful new agent? (Editorial). Br J Anaesth 1990; 65: 607-8. 